\title{
PREGNANT WOMAN KNOWLEDGE ABOUT TOXOPLASMOSIS IN PUSKESMAS LUBUK BAJA, BATAM CITY
}

\author{
Yusmahenry Galindra ${ }^{1}$, Nanang Rudi Utantyo ${ }^{2}$ \\ yusmahenrygalindra@univbatam.ac.id ${ }^{1}$, nanangrudiutantyo@ univbatam.ac.id ${ }^{2}$ \\ Professional Doctor Study Program, Faculty of Medicine, Batam University ${ }^{1}$ \\ Medical Education Study Program, Faculty of Medicine, University of Batam ${ }^{2}$ \\ Jl. Abulyatama No 5 - Kota Batam
}

\begin{abstract}
Background : Toxoplasmosis is an infection caused by Toxoplasma gondii. Toxoplasmosis occurs in eating raw or undercooked food, raw or undercooked meat (such as satay, steak), or touching soil or cat feces that contain parasites. Toxoplasmosis is one of the most dangerous infectious diseases in the mother that results in infant disability and fetal death. The purpose of this study was to determine the knowledge of pregnant women about toxoplasmosis.

Method : The research method used is descriptive, carried out at the Lubuk Baja Health Center, Batam City, the study was conducted for 6 months, the population in this study were all pregnant women who were in the Lubuk Baja Batam City Health Center with a total sample of 98 people, the sampling technique was carried out by using positive techniques Sampling with research instruments using a questionnaire.
\end{abstract}

Result : The results of the study of 98 respondents, there were 54 respondents (55\%) with less knowledge, 32 respondents $(32.6 \%)$ had sufficient knowledge and 12 respondents $(12.2 \%)$ had good knowledge.

Conclusion : Conclusion more than half of the respondents had less knowledge. It is hoped that pregnant women should seek more information related to toxoplasmosis in order to prevent infection

Keywords: knowledge, pregnant women, toxoplasmosis

\section{INTRODUCTION}

Toxoplasmosis is an infection caused by the parasite Toxoplasma gondii. Toxsoplasmosis occurs in eating raw or undercooked food, raw or undercooked meat (such as satay, steak), or touching soil or cat feces that contain parasites. Toxoplasmosis in pregnant women can also be asymptomatic or can give symptoms after birth such as birth babies with congenital abnormalities such as hydrocephalus, abortion / miscarriage, LBW and stillbirths. Toxoplasma gondii transmission increases with gestational age (15-25\% in trimester $1,30-54 \%$ in trimester II, $60-65 \%$ in trimester III). Conversely, the degree of severity will increase if it occurs early in pregnancy (Pohan, 2006).

Toxoplasma gondi can be found worldwide and has infected more than $50 \%$ of the human population in the world. From various studies reported, the prevalence of toxoplasmosis is 50$70 \%$ in France, $46 \%$ in Tanzania, $23.9 \%$ in
Nigeria, $20 \%$ in UK, $12.3 \%$ in China, and $6.7 \%$ in Korea. It was found in Eskimos, namely 1\% in Elsavador, while a very high prevalence was found in Central America, namely 90\%. Seroprevalence of Toxoplasma gondii in Indonesia in humans is still quite high, which is $2 \%-63 \%$ with the highest rate in Lampung Province, $88.23 \%$

Pregnancy is one of the most important periods in a woman's life where there are changes in anatomical, physiological and pathological aspects that can affect the health of the pregnancy and put the mother and baby at risk. One of the pathological aspects that affect the health of pregnancy is Toxoplasma gondii infection. A high prevalence of toxoplasmosis has been reported in pregnant women in Latin America, parts of central or eastern Europe, the Middle East, parts of Southeast Asia and Africa. In the United States, it is reported that $89 \%$ of pregnant women are suspected of 
having an acute infection with Toxoplasma gondand at high risk for transmission to the fetus. Toxoplasmosis transmission in the first trimester of pregnancy is usually difficult to diagnose but can cause more fatal symptoms than infections in other trimesters. The incidence of congenital toxoplasmosis is reported to range from 1-10/10,000 births and of the 4.5 million births per year that occur in the United States and about 500 to 5000 babies suffer from congenital toxoplasmosis. The high seroprevalence of toxoplasmosis antibodies is also influenced by hygiene factors, individual habits, and the culture of Indonesian society. Consumption of contaminated food and the large number of people who have the habit of raising animals, especially cats, also increase the incidence of toxoplasmosis in Indonesia

Based on data from the IDHS (Indonesian Health Demographic Survey) conducted in 2007 , it was recorded that $35 \%$ of pregnant women experienced toxoplasm and in 2008 the incidence of toxoplasma in pregnant women increased to $47 \%$. This condition shows that the incidence of Toxoplasma is increasing every year. The incidence of Toxoplasma may increase if it is not carried out early examination. The effects of this infection can be seen once the baby is born, some are long after birth. So, at birth the baby may appear healthy, but later in its development, symptoms of eye abnormalities appear, such as chorioretinis (vision problems) and strabismus (squint), or hydrocephalus.

Although Toxoplasma infection is highly pathogenic, toxoplasmosis does not always cause a pathological condition in the host, because it has the ability to adapt to the host's body. 8 The infection can be transmitted congenitally (vertically) which only occurs when a woman is infected with T. primary in pregnant women can cause miscarriage, stillbirth, premature birth, malformations and other adverse events. Children with congenital toxoplasmosis may show clinical signs of hydrocephalus, mental retardation, eye disease and other severe sequelae.

There are several factors that are considered risky in Toxoplasma problems, one of which is economic status. Low economic status, tends to consume less clean food, so they are vulnerable to a variety of foods they consume. Apart from low economic status, toxoplasma infection factors are also associated with low personal hygine as well. Eating less clean food can cause pregnant women to become infected with Toxoplasma. In addition to economic status, pregnancy status can also be influenced by the number of times the mother experiences pregnancy. Before deciding pregnancy, every woman should do a toxo test first, so that the pregnancy can run well and healthily. 3 The Jones study, which was conducted in 2008, found that around 761 people (83\%) of 917 pregnant women with primigravida status are at risk of Toxoplasma infection. This is due to the lack of experience of mothers regarding the problem of Toxoplasma infection, so that mothers do not know about how to prevent Toxoplasma infection.

Research shows that about $40 \%$ of pregnant women with Toxoplasma in early pregnancy, the fetus that is born will be infected and $15 \%$ will experience abortion or early birth. About $17 \%$ of fetuses are infected in the 1 st trimester, $24 \%$ in the 2 nd trimester, and $62 \%$ in the $3 \mathrm{rd}$ trimester. In general, $90 \%$ of infected babies can be born normally but $80 \%-90 \%$ of these babies can suffer from visual disturbances to blindness after a few months or some. years after birth and $10 \%$ of them may develop hearing loss.

In the city of Batam in 2016 according to data from hospital medical records, Santa Elisabet Lubuk Baja Batam City this disease has often occurred in pregnant women, as many as 242 pregnant women who experienced abortion caused by toxsoplasma gondii

Based on the above background, as well as realizing the importance of knowledge of pregnant women about the dangers of the Toxoplasma gondii virus, the researchers are interested in conducting research on "Knowledge of Pregnant Women about Toxoplasmosis.

\section{RESEARCH PURPOSES}

This research aims to determine the frequency distribution of knowledge of pregnant women about toxoplsmosis at Lubuk Baja Public Health Center

\section{RESEARCH METHODS}


The research method used is descriptive, carried out at the Lubuk Baja Health Center, Batam City, the study was conducted for 6 months, the population in this study were all pregnant women who were in the Lubuk Baja Batam City Health Center with a total sample of 98 people, the sampling technique was carried out by using positive techniques Sampling with research instruments using a questionnaire

The data collected in this study using primary data which is the result of direct interviews with the sample with a questionnaire containing 28 questions. The collected data were analyzed using computer software which is intended to describe the level of knowledge of pregnant women about toxoplasmosis.

\section{RESEARCH RESULT}

From research conducted on 98 respondents, it was found:

Based on the characteristics of the majority of respondents with high school education, as many as 51 people (52\%), 2 respondents had a high education $(2 \%), 44$ people $(44.9 \%)$ had a junior high school education and 1 person had an elementary education.

Based on age, most of the respondents were in the age range of 20 - 35 years, namely 67 respondents $(68.7 \%)$ and most of them were housewives, as many as 79 respondents $(80.6 \%)$

Of the 98 respondents, 54 respondents (55\%) had less knowledge, 32 respondents (32.6\%) had sufficient knowledge and 12 respondents $(12.2 \%)$ had good knowledge

\section{DISCUSSION}

From the research conducted on 98 respondents, 54 respondents $(55 \%)$ had less knowledge

According to Notoatmodjo (2010) Knowledge is the result of tofu and this occurs after people sense a certain object. Sensing occurs through the human senses, namely the senses of sight, hearing, smell, taste and touch. A person's knowledge is influenced by experience, either directly or indirectly. Direct experience, for example, personal experience obtained through reading, while indirect experience, for example, the experience of others conveyed to someone through information about a problem. In this case it is closely related to the lack of knowledge of pregnant women where the knowledge of pregnant women is still lacking about Toxoplasma gondii because they just know about toxsoplasma gondii.

One of the factors that influence the knowledge of mothers is the level of education of pregnant women who on average are high school graduates / equivalent. This is in accordance with Sumolang's research in 2014 in Palu City which stated that fertile women who know about toxoplasmosis are still very low, namely $24.1 \%$ who have heard or known about this infection.

The results of this study are in line with Andriyani (2015) "Risk Factors Associated with the Incidence of Toxoplasma Infection in Pregnant Women at Arifin Ahmad Hospital Pekanbaru, namely that the variable significantly related to the incidence of toxsoplasma is the educational variable ( $\mathrm{p}$ value 0.003 ) with the number of respondents 30 pregnant women who infected with toxsoplasma.

This is thought to be closely related to education. The majority of couples of childbearing age have junior high school education and the environment is all conditions that exist around humans and their effects that can affect the development and behavior of people or groups.

About $45 \%$ of pregnant women who experience Toxoplasma infection are caused by low levels of education. The existence of a low level of education makes it difficult for people to obtain information, especially the problem of toxoplasmosis in pregnant women, so that pregnant women who are less knowledgeable about toxoplasmic infections do not know how to prevent Toxoplasma. infected and 15\% had abortion or early birth

The results of this study are in line with Sari's research in 2011 which had the highest toxoplasma infection in the secondary education group, namely junior high school $(75 \%)$. Education may be one of the factors that can affect the health of pregnant women associated with Toxoplasma infection. This can happen because pregnant women with low education do not seek information about the 
disease so that the knowledge and abilities of mothers in preventing Toxoplasma infection are ineffective.

Several studies have shown that lower levels of education are more likely to suffer from toxoplasmosis than those with higher education (Nissapatorn et al., 2011, Chiang et al., 2012). Likewise, research in Saudi shows that the higher the level of education, the better the prevention behavior (Nissapatorn et al., 2011) there is a relationship between knowledge and toxoplasmosis.

Meanwhile, the respondents' knowledge increased after being given health promotion about toxsoplasma gandii. Where the information factor greatly affects the increase in one's knowledge and this is in line with the theory put forward by Notoatmodjo (2012).

In addition, a lack of awareness of toxoplasmosis could result from a lack of access to information related to Toxoplasma infection, especially among pregnant women. In this study, of the 98 respondents, only $15.1 \%$ of respondents admitted to having heard, read or seen information related to toxoplasmosis. All respondents in this study claimed to have never undergone a toxoplasmosis test / screening.

Pregnant women who know / have heard about toxoplasmosis are very low (15\%), where the most information is obtained from print media $(60.1 \%)$ compared to other sources of information. Generally, respondents did not know the symptoms of toxoplasmosis where the majority of respondents answered that they did not know the symptoms. According to respondents, toxoplasmosis can be transmitted through contact with cats or through consumption of undercooked meat foods such as satay. Most respondents know that in order not to contract toxoplasmosis, respondents must maintain personal hygiene and avoid contact with animals. Almost all respondents know that animals can transmit toxoplasmosis (92.9\%), including cats, dogs, rats, etc.

Eating undercooked meat is a favorite food for certain people, especially goat satay. $\mathrm{T}$. gondi can survive at temperatures up to $66 \mathrm{oC}$, so that if the meat is only heated half-cooked, it is possible that toxoplasma in the form of a cyst inside the satay meat is still not dead. Research by Sasmita (2001) shows that the incidence of toxoplasmosis in goats in Surabaya is $42.4 \%$, while in Malang it is 40\% (Wiyarno, 2008). The high results of these studies support the transmission of toxoplasmosis to humans, especially for people who like to eat halfcooked goat satay.

(Nissapatorn et al., 2011). However, research in Iran states that there is no relationship between education and toxoplasmosis (Mostafavi et al., 2012). Research in Poland shows that health education can improve knowledge and behaviors to prevent toxoplasmosis (Pawlowski et al., 2001). Most of the respondents (59.3\%) were housewives who did their daily work at home. Research in Saudi shows that more infections are found in housewives, both who live in cities and in rural areas, compared to those who do other jobs (Amin et al., 2013). This is possible because the intensity of contact with the source of infection in housewives is higher than those who work, especially if the family has pets such as cats.

This explains that better health education is needed to increase awareness of a clean and healthy lifestyle. Good knowledge and awareness of toxoplasmosis can guide pregnant women in protecting themselves from this parasitic infection. Apart from factors such as age group, level of education, amount of parity and consumption of undercooked meat, level of knowledge and attitudes towards toxoplasmosis showed a significant association with Toxoplasma seropositivity. The most common preventive action that mothers can take during their pregnancy is by routinely checking their pregnancy at a health facility

\section{CONCLUSION}

From research conducted on 98 respondents obtained

Of the 98 respondents, 54 respondents (55\%) had less knowledge, 32 respondents $(32.6 \%)$ had sufficient knowledge and 12 respondents $(12.2 \%)$ had good knowledge

\section{SUGGESTION}

1. Educational Institutions

The results of this study are expected to become a reference material for the head of the obstetrics study program and other institutions in increasing knowledge among educational 
institutions about toxsoplasma gondii its impact on pregnant women by conducting health seminars.

\section{Health Workers}

The results of this study can become a reference for the importance of disseminating information about toxsoplasma gondii and the dangers for pregnant women, considering that there are still many pregnant women in the Batu Aji Community Health Center who do not know about Toxsoplasma Gondii.

\section{For Further Researchers}

It is hoped that the results of this study can be developed with different methodologies for both qualitative and quantitative so that it can enrich about toxsoplasma gondii and it is recommended for further researchers to carry out health promotion

\section{Society}

People can care more, especially pregnant women, about toxsoplama gondii.

\section{DAFTAR PUSTAKA}

Ani Triana, 2015. Faktor derteminan toksoplasmosis pada ibu hamil. Jurnal kesehatan masyarakat stikes hang tuah pekan baru

Dinas Kesehatan Batam, 2015. Batam : Dinkes Kota Batam.

Departemen Kesehatan RI, Pusat Promosi Kesehatan, Panduan Pelatihan Komunikasi Perubahan Perilaku, Untuk KIBBLA, Jakarta 2008.

Departemen Kesehatan RI, Pusat Promosi Kesehatan, Pedoman Pengelolaan Promosi Kesehatan, Dalam Pencapaian PHBS, Jakarta 2008 .

Irianto, 2014. Buku Memahami Berbagai Macam Penyakit. Alfabeta.

Lestari, Ayu (2015). Pengaruh Pemberian Informasi Terhadap Peningkatan Pengetahuan Tentang Bahaya Narkoba Pada Remaja Di SMA !4 Kelurahan Sengkuan Kecamatan Batu Ampar Kota Batam. Karya Tulis Ilmiah Tidak diterbitkan. Universitas Batam. Batam.

Lapau, Buchari. 2013. Metode Penelitian Kesehatan (Edisi Revisi). Jakarta : Yayasan Pustaka Obor Indonesia.

Mubarak, Wahit, Iqbal, Dkk. 2011. Promosi Kebidanan Untuk Kebidanan. Jakarta : Salemba Medika.
Notoatmodjo, Soekidjo. 2010. Promosi Kesehatan Teori dan Aplikasi (Edisi Revisi). Jakarta : Rineka Cipta

Notoatmodjo, Soekidjo. 2012. Pendidikan Promosi dan Perilaku Kesehatan. Jakarta: Rineka Cipta

Notoadmodjo, 2010. Metode Penelitian Kesehatan. Jakarta : Rineka Cipta.

Notoadmodjo, Soekidjo. Promosi Kesehatan Teori Dan Aplikasi (Edisi Revisi). Jakarta : Rineka Cipta.

Profil Dinas Kesehatan Profinsi Kepulauan Riau, 2015.

Pohan, 2016. Pengaruh Pemberian Penyuluhan Tentang Toxsoplasmosis Terhadap Prilaku Kesehatan Pada Wanita Usia Subur Disusun Tulung Srihardono Pundong Bantul.Naskah Publikasih . Sekolah Tinggi Ilmu Kesehatan ' Aisyayah Yogyakarta, 2010.

Rumah Sakit Santa Elisabet Kota Batam Lubuk Baja.

Soedarto, 2010. Toksoplasmosis Mencegah Dan Mengatasi Penyakit Melindungi Ibu Dan Anak. Agung Seto.

Url:Http://Www.Microbeworld.Org/Images/St ories) Intracellulair Tachyzoite toxoplasma Gondii.

url. http://batam.tribunnews.com/2 017/03/04/ pukul 17:15 ternyata-begini-prosespenularan-toksoplasama-pada-wanitahamil).

Vanessa J. T. Seran, 2016. Seroepidemiologi toksoplasmosis pada masyarakat di Desa Kumu Kabupaten Minahasa tahun 2015. 